\title{
The Evaluation of Saliva Flow Rate, pH, Buffer Capacity, Microbiological Content and Indice of Decayed, Missing and Filled Teeth in Behçet's Patients
}

Vildan Erdem¹, Mehmet Yıldı' ${ }^{1}$, Teoman Erdem²

${ }^{1}$ Department of Dentistry, Atatürk University Dental Faculty, Erzurum, Turkey

${ }^{2}$ Department of Dermatology, Sakarya University Faculty of Medicine, Sakarya, Turkey

\begin{abstract}
Background: Several lines of evidence indicate that oral microbial flora play a critical role in the pathogenesis of Behçet disease. Saliva flow rate, buffer capacity and microorganism content are very important in the maintenance of oral health.

Aims: We aimed to evaluate saliva flow rate, $\mathrm{pH}$, buffer capacity and Streptococcus mutans and Lactobacilli content along with the decayed, missing, and filled tooth index in Behçet's patients.

Study Design: Case-control study

Methods: Forty patients with active Behçet disease [female:male (F/M) 21/19, mean age 31.05 \pm 11.08 years] and forty healthy persons (F/M 21/19, mean age 31.03 \pm 9.14 years) were included in the study. The oral region was first examined, and the decayed, missing, and filled tooth index was calculated for each person. Stimulated saliva was collected and divided into two separate millimetric tubes to calculate the buffer capacity of the saliva, determine Streptococcus mutans and Lactobacilli levels and measure the $\mathrm{pH}$ of the saliva. A Caries Risk Test buffer strip was used to calculate the buffer capacity. Caries Risk Test bacterial kit was used to determine Streptococcus mutans and lactobacilli levels. A pH meter was used to measure the pH of the saliva.

Results: The mean saliva $\mathrm{pH}$ of the patients was higher than the controls $(7.76 \pm 0.51,7.18 \pm 0.46$, respectively) $(p<0.001)$. The mean level of $S$ treptococcus mutans and Lactobacilli in patients was higher than controls $(p<0.05)$. The mean decayed, missing, and filled tooth index of patients was $9.82 \pm 6.59$ (range 1-28), while the mean decayed, missing, and filled tooth index of the controls was $6.05 \pm 3.35$ (range 1-16) $(p<0.01)$. There were no significant differences between the patients and the controls with respect to saliva flow rate and saliva buffer capacity $(p>0.05)$.

Conclusion: We think that the maintenance of oral health by effective, regular tooth brushing, regular dental check-ups and dental treatment for Behçet patients is very important for the prevention and therapy of Behçet disease.
\end{abstract}

Key Words: Behçet syndrome, saliva, DMFT index, Lactobacilli, Streptococcus mutans.

Received: 15.10 .2012

Accepted: 29.01.2012

\section{Introduction}

Behçet's disease (BD), a multisystem inflammatory disorder, is characterised by mucocutaneous, ocular, arthritic, vascular, central nervous and gastrointestinal system involvement. It was first described by the Turkish dermatologist Hulusi Behçet in 1937 as "recurrent oral aphthous ulcers, genital ulcers, and "hypopyon-uveitis" (1). The aetiology and pathogenesis of BD has not been fully clarified. Several lines of evidence indicate that oral microbial flora play a critical role in the pathogenesis of BD. Various clinical and basic data also strongly point to an infectious triggering agent in the pathogenesis of $\mathrm{BD}(2$, 3). The relationship between streptococcal infection and BD can also explain the clinical observations, such as increased oral manifestations after dental treatment, hypersensitivity to streptococcal skin tests, elevated pro-inflammatory cytokine responses to streptococcal antigens (4-7) and recent reports of beneficial antibacterial therapy $(8,9)$.
In patients with $\mathrm{BD}$, poor oral health, poor prognosis for natural dentition, an increased number of extracted teeth due to multiple carious lesions and changes in oral $\mathrm{pH}$ have been reported (10-12). In addition, an increased incidence of tonsillitis and aggravation of disease by dental treatment are seen in BD patients.

Saliva plays a critical role in the maintenance of oral health. Saliva provides many features, such as lubrication and protection, buffering action and clearance, maintenance of tooth integrity, and antibacterial activity (13). Saliva flow rate, buffer capacity and microorganism content are very important for oral health.

We aimed to evaluate saliva flow rate, $\mathrm{pH}$, buffer capacity and Streptococcus mutans (S. Mutans) and Lactobacilli content and DMF index (index of decayed, missing, and filled teeth ) in BD, since studies related to this issue are scant and results of these studies are inadequate. 


\section{Materials and Methods}

The study was performed together with the Atatürk University Dental Faculty Restorative Dental Department and the Medical Faculty Dermatology Department.

Forty active BD patients [female:male (F/M) 21/19, mean age $31.05 \pm 11.08 \mathrm{yr}$ ] diagnosed according to the International Study Group for BD (ISG) criteria (14) and forty healthy persons ( $F / M$ 21/19, mean age 31.03 $\pm 9.14 \mathrm{yr}$ ) were also included in the study. If the patients had at least one clinical sign according to ISG criteria, they were accepted as having active BD.

The inclusion criteria for the patient group were: lack of other oral or systemic disorders from BD, persons not using an orthodontic apparatus, no colchicine medication in the last month, non-smoking, and non-pregnant.

The control group was selected randomly from healthy people who accompanied BD patients attending our clinics, and staff of our hospital. The inclusion criteria for the control group were: having no symptoms of any disorder, persons who had not used an orthodontic apparatus or taken any medicine during the last month, non-smoking, and nonpregnant. Healthy controls were matched with regard to age, gender and socio-economic status.

The study was approved by the Atatürk University Institute of Healthy Science and information consent was given by the patients at the time of study entry.

\section{Assessment of general status}

Patients and controls were instructed to collect data on a chart about their frequency of tooth brushing, degree of education and duration since the last dental visit.

\section{Assessment of oral health}

To determine oral health status, patients and controls were examined, and extracted teeth, carious teeth and filled teeth were recorded. We used the DMFT index that measures the amount of permanent teeth decayed, missing, and filled in the individual's mouth, ranging from 0 to 32 . The DMFT index was calculated for each person.

\section{Collection of saliva and calculation of saliva flow rate}

Stimulated whole saliva was collected under resting conditions in a quiet room (to reduce any stressful conditions). The saliva samples were obtained two hours after breakfast, between 9-12 a.m. Two hours prior to the evaluation of stimulated whole saliva production, subjects were instructed not to eat, drink, chew gum, or rinse their mouths until the test was completed. Pre-stimulation was accomplished by chewing a piece of standard size paraffin, and the participants were asked to swallow the saliva pooled in the mouth after $60 \mathrm{~s}$. Thereafter, whole stimulated saliva was collected for about 5 min into a dry, millimetric and sterilised plastic tube. The flow rate was calculated in $\mathrm{ml} / \mathrm{dk}$. The saliva collected was divided into two separate millimetric tubes to calculate the buffer capacity of the saliva, to determine $S$. mutans and Lactobacilli levels and to measure the $\mathrm{pH}$ of the saliva.

\section{Calculation of buffer capacity and measurement of saliva pH}

The saliva buffer capacity was measured using strips (Caries Risk Test (CRT) buffer strip, Ivoclar Vivadent Schaan/Liechtenstein) and measured against standards assigned by the manufacturer. A pH meter (Mettler Toledo MP 220 pH Meter, Schwarzenbach, Switzerland) was used to measure saliva $\mathrm{pH}$.

\section{Microbiological analysis}

A CRT bacteria kit (Ivoclar Vivadent, Schaan, Liechtenstein) was used to determine $S$. mutans and lactobacilli levels. Saliva samples were dropped on the CRT bacteria kit media by pipette. After incubation at $37^{\circ} \mathrm{C}$ for 48 hours, viable colonies were measured. The salivary counts of lactobacilli and $S$. mutans determined by the number of colony forming units (CFU) were measured semi-quantitatively. The results were expressed as two values: $<10^{5} \mathrm{CFU}$ and $\geq 10^{5} \mathrm{CFU}$.

\section{Statistical analysis}

Data were analysed using the SPSS 11.0 statistical program (SPSS Inc., Chicago, IL, USA). Chi-square test and Students $t$-test were used in the analysis. $\mathrm{P} \leq 0.05$ was accepted as significant.

\section{Results}

The mean duration of BD was 3.7 months (range 1-120 months). In 9 patients, BD was diagnosed first. 25 patients were using colchicine; the remaining patients did not use any treatment. Clinical manifestations of the BD patients are given in Table 1.

According to the frequency of tooth brushing and degree of education, there were no significant differences between patients and controls $(p>0.05)$. The duration since the last dental visit was significantly lower in patients than in controls $(p<0.001)$.

The mean saliva $\mathrm{pH}$ of the patients was higher than controls $(7.76 \pm 0.51,7.18 \pm 0.46$, respectively) $(p<0.001)$. The mean level of $S$. mutans and Lactobacilli in patients was higher than controls $(p<0.05)$. The mean DMFT index of patients was $9.82 \pm 6.59$ (range 1-28), while the mean DMFT index of the controls was $6.05 \pm 3.35$ (range 1-16). There was a significant difference between the patients and the controls with respect to DMFT index $(p<0.05)$. There were no significant differences between the patients and the controls with respect to saliva flow rate and saliva buffer capacity ( $p>0.05$ ) (Table 2-4).

Table 1. The clinical manifestations of Behçet's Disease patients

\begin{tabular}{|lc|}
\hline Finding & $\mathbf{n}(\%)$ \\
\hline Oral ulcer & $40(100)$ \\
Genital ulcer & $40(100)$ \\
Erythema nodosum & $24(60)$ \\
Arthritis & $20(50)$ \\
Vascular involvement & $5(12.5)$ \\
Uveitis & $12(30)$ \\
\hline *BD: Behçet's Disease & \\
\hline
\end{tabular}




\section{Discussion}

Behçet's disease usually starts in oral mucosa, and other clinical manifestations of the disease are seen after oral ulcers. The relationship between oral environment and BD pathogenesis can be summarised as: oral ulcers are the most common and usually the first clinical manifestation of BD, an augmented immune response to oral streptococci is observed in BD patients, and finally an increased incidence of tonsillitis and dental caries, and aggravation of the disease by dental treatment are important observational clues in clinical practice. Oral health is impaired in BD and associated with disease severity $(3,4,8,15)$.

Saliva plays an important role in oral health monitoring, and in regulating and maintaining the integrity of the oral hard tissues and some soft tissues. Saliva has many essential functions. Clinically, a more important role is in the maintenance of oral health, including the protection of teeth and mucosa from infections. Variations in salivary flow may be affected, reversibly or irreversibly, by numerous physiological and pathological factors. Decreased salivary flow results in clinically significant oral discomfort that may manifest as increased caries, susceptibility to oral infections, oral candidiasis, altered taste sensation or as a host of other problems. Similarly, decreased saliva flow rate may play a role in the pathogenesis of BD. Salivary buffering capacity has been identified as one of the many factors that may affect an individual's caries risk. The ability of saliva to buffer acids is essential for maintaining $\mathrm{pH}$ values in the oral environment above a critical $\mathrm{pH}$, thereby protecting teeth against demineralisation (15-18).

Also, saliva flow rate of our patients was higher than controls, although the difference was not statistically meaningful. We thought that saliva flow rate might be increased with oral ulcers. Unfortunately, we could not identify any studies concerned with saliva flow rate in BD.

There have been a few studies of saliva buffering capacity and $\mathrm{pH}$ in $\mathrm{BD}$. Şengün et al. observed that the mean sali-

Table 2. The saliva flow rate, saliva $\mathrm{pH}$, and DMFT* index of patients and controls

\begin{tabular}{|lccc|}
\hline & $\begin{array}{c}\text { Patient } \\
\text { group }\end{array}$ & $\begin{array}{c}\text { Control } \\
\text { group }\end{array}$ & $\begin{array}{c}\mathbf{p} \\
\text { value }\end{array}$ \\
\hline $\begin{array}{l}\text { Saliva flow rate } \\
\mathrm{mL} / \mathrm{min}\end{array}$ & $1.44 \pm 0.52$ & $1.41 \pm 0.50$ & 0.757 \\
$\begin{array}{l}\text { Saliva } \mathrm{pH} \\
\text { DMFT index }\end{array}$ & $7.76 \pm 0.51$ & $7.18 \pm 0.46$ & 0.000 \\
\hline DMFT: Decayed, missing and filled teeth & \\
p<0.05(According to Mann Whitney U test) & \\
\hline
\end{tabular}

Table 3. The saliva buffer capacity of patients and controls

\begin{tabular}{|c|c|c|c|c|c|c|c|c|}
\hline \multirow[t]{2}{*}{ Group } & \multicolumn{2}{|c|}{ Low } & \multicolumn{2}{|c|}{ Medium } & \multicolumn{2}{|c|}{ High } & \multirow[t]{2}{*}{$\chi^{2}$} & \multirow[t]{2}{*}{$p$} \\
\hline & $n$ & $\%$ & $\mathrm{n}$ & $\%$ & $\bar{n}$ & $\%$ & & \\
\hline Patient & 3 & 7.5 & 11 & 27.5 & 26 & 65 & 1.324 & $0.557^{\star \star \star}$ \\
\hline Control & 1 & 2.5 & 14 & 35 & 25 & 62.5 & & \\
\hline
\end{tabular}

Fisher's Exact Test ${ }^{\star}, \mathrm{p}>0.05^{\star \star}$ vary $\mathrm{pH}$ in $\mathrm{BD}$ patients was $7.15 \pm 0.39$ and the buffering capacity was $3.68 \pm 0.80$. The mean salivary $\mathrm{pH}$ in controls was $6.94 \pm 0.43$ and the buffering capacity was $3.48 \pm 0.50$. There were no significant differences in $\mathrm{pH}$ and buffering capacity between the groups. In our study, similar to this study, saliva $\mathrm{pH}$ was higher than in controls (19). Feslihan also observed that there was no significant difference between patients with $\mathrm{BD}$ and controls with respect to saliva buffering capacity (20).

Both Şengün et al. and Mumcu et al. observed that there was no significant difference in DMFT index between BD patients and controls. However, we found that the DMFT index of $B D$ patients was significantly higher than controls $(19,21)$.

Oral health is impaired in BD and associated with disease severity (22). Less tooth brushing and a longer period since the last dental visit in BD may be associated with the poor oral hygiene conditions caused by active painful oral ulcers. Akman et al. observed that the daily frequency of tooth brushing was lower in BD patients than in controls, but the difference was not statistically significant, similar to our study (23).

Mumcu et al. (24) observed the frequency of tooth brushing to be significantly lower in Turkish patients when compared with those in the UK. We found that there was no difference between BD patients and controls according to the frequency of tooth brushing, but the duration since the last dental visit was significantly higher in $\mathrm{BD}$ patients than in controls.

As BD starts mostly from the oral mucosal surfaces (oral aphthae being the first manifestation in $70 \%$ of patients), oral microbial flora have long been implicated in the pathogenesis. The relationship between streptococcal infections and BD can also explain the clinical observations. Patients with BD have a significantly higher incidence of tonsillitis and dental caries. Systemic symptoms of BD could thus be induced after treatment of dental caries or even by intracutaneous injection of streptococcal antigens. Recent reports have shown that antibacterial treatment is beneficial in $\operatorname{BD}(8,25)$.

Mumcu et al. (26) observed that high levels of salivary S. mutans colonisation was significantly more present in BD than controls. The presence of $S$. mutans in saliva was associated with oral ulcers $(61.5 \%$ in patients with active oral ulcers vs. $38.9 \%$ in inactive ulcers; $p=0.020$ ). $S$. mutans colonisation in saliva was significantly higher among male BD patients with a severe disease course compared to a milder disease.

We also found that the mean level of Lactobacilli in BD patients was significantly higher than controls. We could not find any study related to lactobacilli in BD in the literature.

Table 4. The level of $S$. mutans and Lactobacilli of patients and controls

\begin{tabular}{|c|c|c|c|c|}
\hline Group & $\begin{array}{c}<10^{5} \mathrm{cfu} \\
\mathrm{n} \%\end{array}$ & $\begin{array}{c}\geq 10^{5} \mathrm{cfu} \\
\mathrm{n} \%\end{array}$ & $\chi^{2 \star}$ & $p$ \\
\hline \multicolumn{5}{|c|}{ S. mutans } \\
\hline Patient & 1332.5 & $27 \quad 67.5$ & 6.084 & $0.014^{\star *}$ \\
\hline Control & 2460 & 1640 & & \\
\hline \multicolumn{5}{|c|}{ Lactobacilli } \\
\hline Patient & $17 \quad 42.5$ & $23 \quad 57.5$ & 4.073 & $0.044^{\star *}$ \\
\hline Control & $26 \quad 65$ & $14 \quad 35$ & & \\
\hline
\end{tabular}


It is possible that chronic infection of oral mucosal structures in genetically susceptible patients could accelerate BD by promoting a chronic systemic inflammatory status through the release of bacterial products, heat shock proteins (HSP), acute-phase reactants and other inflammatory mediators. Since BD starts mostly from the oral mucosal surfaces, it is possible that the immune response to microorganisms in saliva might initially cause elevation of the inflammatory mediators locally, which consequently enters the systemic circulation and, by interacting with endothelial tissues, plays a role in the pathogenesis of BD. This view is supported in that BD usually begins with recurrent oral ulcers, followed by later signs of BD (27).

It is suggested that an immune response to streptococcal HSP might also be directed to epithelial and other human 60kDa HSPs, although there was a lack of specificity. It is thus possible that antigens other than these HSP-related peptides might be involved in the pathogenesis of BD (28).

In conclusion, we believe that the maintenance of oral health by effective, regular tooth brushing and dental flossing, regular dental check-ups and dental treatments in patients with Behçet is very important for the prevention and therapy of BD.

Ethics Committee Approval: Ethics committee approval was received for this study.

Informed Consent: Written informed consent was obtained from patients who participated in this study.

Peer-review: Externally peer-reviewed.

Author contributions: Concept - V.E.; Design - V.E.; Supervision M.Y.; Resource - V.E.; Materials - V.E.; Data Collection\&/or Processing - V.E.; Analysis\&/or Interpretation - V.E., T.E.; Literature Search - V.E.; Writing - V.E., T.E.; Critical Reviews - M.Y.

Conflict of Interest: No conflict of interest was declared by the authors.

Financial Disclosure: No financial disclosure was declared by the authors.

\section{References}

1. Behçet H. Uber rezidivivierende aphthose, durch ein virus verursachte geschwure am mund, am auge und anden genitalien. Dermatol Wochenschr 1937;105:1152-7.

2. Isogai $E$, Ohno $S$, Kotake $S$, Isogai $H$, Tsurumizu T, Fujii N, et al. Chemiluminescence of neutrophils from patients with Behc, et's disease and its correlation with an increased proportion of uncommon serotypes of Streptococcus sanguis in the oral flora. Arch Oral Biol 1990;35:43-8. [CrossRef]

3. Mizushima Y, Matsuda T, Hoshl K, Ohno S. Induction of Behçet's disease symptoms after dental treatment and streptococcal antigen skin test. J Rheumatol 1988;15:1029-30.

4. Yoshikawa K, Kotake S, Sasamoto Y, Ohno S, Matsuda H. Close association of Streptococcus sanguis and Behcet's disease. Nippon Ganka Gakkai Zasshi 1991;95:1261-7.

5. Mizushima Y. Behçet's Disease Research Committee of Japan. Skin hypersensitivity of streptococcal antigens and the induction of systemic symptoms by the antigens in Behcet disease. J Rheumatol 1989;16:506-11.

6. Mizushima Y, Matsuda T, Hoshl K, Ohno S. Induction of Behcet's disease symptoms after dental treatment and streptococcal antigen skin test. J Rheumatol 1988;15:1029-30.
7. Lehner T. The role of heat shock protein, microbial and autoimmune agents in the aetiology of Behçet's disease. Int Rev Immunol 1997;14:21-32. [CrossRef]

8. Kaneko F, Oyama N, Nishibu A. Streptococcal infection in the pathogenesis of Behçet's disease and clinical effects of minocycline on the disease symptoms. Yonsei Med J 1997;38:444-54.

9. Calgüneri M, Ertenli I, Kiraz S, Erman M, Celik I. Effect of prophylactic benzathine penicillin on mucocutaneous symptoms of Behçet's disease. Dermatology 1996;192:125-8. [CrossRef]

10. Çelenligil-Nazliel H, Kansu E, Ebersole JL. Periodontal findings and systemic antibody responses to oral microorganisms in Behçet's disease. J Periodontol 1999;70:1449-56. [CrossRef]

11. Carl W, Havens J, Kielich M. Behcet's disease: dental and oral soft tissue complications. Quintessence Int 2000;31:113-6.

12. Yosipovitch G, Kaplan I, Calderon S, David M, Chan YH, Weinberger $\mathrm{A}$. Distribution of mucosal $\mathrm{pH}$ on the bucca, tongue, lips and palate. A study in healthy volunteers and patients with lichen planus, Behcet's disease and burning mouth syndrome. Acta Derm Venereol 2001;81:178-80. [CrossRef]

13. Humphrey SP, Williamson RT. A review of saliva: Normal composition, flow, and function. J Prosthet Dent 2001;85:162-9. [CrossRef]

14. International Study Group for Behçet's Disease. Criteria for diagnosis of Behçet's disease. Lancet 1990;335:1078-80.

15. Tojo $M$, Yanagihori $H$, Zheng $X$, et al. Bes-1 DNA fragment encoding streptococcal antigen in skin lesions from patients with Behçet's disease. J Appl Res 2003;3:232-8.

16. Sreebny LM. Saliva: Its role in health and disease. Int Dent Res 1992;42:287-304.

17. Scott J. Structure and function in aging human salivary glands. Gerodontol 1987;5:149-58. [CrossRef]

18. Sreebny LM. Saliva in health and disease: an apprasial and update. Int Dent Res 2000;50:140-61. [CrossRef]

19. Şengün A, Duran $i$, Botsalı $H E$, Dönmez N. Behçet hastalığı olan kişilerde tükürük $\mathrm{pH}$ 'sı, tamponlama kapasitesi ve çürük insidansının değerlendirilmesi. SÜ Diş Hek Fak Derg 2008;17:1-5.

20. Feslihan Ş. Behçet hastalığında oral ülserasyona eşlik eden bazı tükürük ve serum bileşenlerinin incelenmesi. Marmara Üniversitesi Sağlık Bilimleri Enstitüsü Oral Biyoloji, Yüksek Lisans Tezi, Istanbul, 2003.

21. Mumcu G, Ergun T, Inanc N, Fresko I, Atalay T, Hayran O, et al. Oral health is impaired in Behçet's disease and is associated with disease severity. Rheumatology (Oxford) 2004;43:1028-33. [CrossRef]

22. Karacayli U, Mumcu G, Simsek I, Pay S, Kose O, Erdem H, et al.The close association between dental and periodontal treatments and oral ulcer course in behcet's disease: a prospective clinical study. J Oral Pathol Med 2009;38:410-5. [CrossRef]

23. Akman A, Kacaroglu H, Donmez L, Bacanli A, Alpsoy E. Relationship between periodontal findings and Behçet's disease: a controlled study. J Clin Periodontol 2007;34:85-91. [CrossRef]

24. Mumcu G, Niazi S, Stewart J, Hagi-Pavli E, Gokani B, Seoudi N, et al. Oral health and related quality of life status in patients from UK and Turkey: a comparative study in Behcet's disease. J Oral Pathol Med 2009;38:406-9. [CrossRef]

25. Hirohata S, Kikuchi H. Behçet's disease. Arthritis Res Ther 2003;5:139-46. [CrossRef]

26. Mumcu G, Inanc N, Aydin SZ, Ergun T, Direskeneli H. Association of salivary $\mathrm{S}$. mutans colonisation and mannose-binding lectin deficiency with gender in Behçet's disease. Clin Exp Rheumatol 2009;27(2 Suppl 53):S32-6.

27. Direskeneli H. Behçet's disease: Infectious etiology, new autoantigens, and HLA-B51. Annals of Rheumatic Disease 2001;90:996-1002. [CrossRef]

28. Pervin K, Childerstone A, Shinnick T, Mizushima $Y$, van der Zee $R$, Hasan A, et al. T cell epitope expression of mycobacterial and homologous human 65-kilodalton heat shock protein peptides in short term cell lines from patients with Behçet's disease. J Immunol 1993;151:2273-82. 